\title{
Biological activities of lipoteichoic acid and peptidoglycan-teichoic acid of Bacillus subtilis 168 (Marburg)
}

\author{
J.-P. Himanen, ${ }^{1 *}$ L. Pyhälä, ${ }^{1}$ R.-M. Ölander, ${ }^{1}$ O. Merimskaya, ${ }^{2}$ T. Kuzina, ${ }^{2}$ O. Lysyuk, ${ }^{2}$ \\ A. Pronin, ${ }^{2}$ A. SANin, ${ }^{2}$ I. M. Helander ${ }^{1}$ and M. SARVAS ${ }^{1}$ \\ ${ }^{1}$ National Public Health Institute, Mannerheimintie 166, FIN-00300 Helsinki, Finland \\ ${ }^{2}$ The Gamaleya Institute for Epidemiology and Microbiology, Gamaleya Street 18, 123098 Moscow, Russia
}

(Received 19 March 1993; revised 4 June 1993; accepted 1 July 1993)

\begin{abstract}
To evaluate the suitability of Bacillus subtilis as a production host of heterologous proteins for pharmaceutical purposes, we assessed the biological activity of this bacterium and its major cell envelope components, lipoteichoic acid (LTA) and peptidoglycan-teichoic acid complex (PG-TA) in several eukaryotic effector assays. LTA and PG-TA were found to be non-toxic for mice and guinea-pigs in a short-term toxicity assay. PG-TA was weakly pyrogenic and weakly mitogenic. Both LTA and PG-TA acted as immunologic adjuvants in mice and when injected in mice, also caused an increase in the number of granulocyte-monocyte colony-forming cells in the bone marrow probably via stimulation of production of granulocyte-macrophage colony-stimulating factor.
\end{abstract}

\section{Introduction}

The production of heterologous proteins in Bacillus subtilis for vaccine purposes has been suggested for several reasons. This bacterium is widely used in industry (Debabov, 1982; Harwood, 1992) and efficient expression systems have been developed for the production of proteins either intracellularly or in secreted form (Sarvas et al., 1990). B. subtilis is nonpathogenic and devoid of known toxic components, including endotoxin. We have previously described the use of $\boldsymbol{B}$. subtilis as a host to produce several vaccine protein candidates, e.g. the subunits of pertussis toxin (Runeberg-Nyman et al., 1987; Himanen et al., 1990) and the class 1 outer membrane protein (P1) of Neisseria meningitidis (Nurminen et al., 1992). The heterologous proteins could be purified to contain only small amounts (less than $1 \%$ ) of lipoteichoic acid (LTA) and peptidoglycan-teichoic acid complex (PG-TA), the most abundant of the many cell envelope components of $B$. subtilis (Himanen et al., 1993).

* Author for correspondence. Present address: University of Turku, Finnish-Russian Joint Biotechnology Laboratory, FIN-20520 Turku, Finland. Tel. +358216338061 ; fax +358216338080 ; e-mail JUHAHI@sara.cc.utu.fi.

Abbreviations: ConA, Concanavalin A; DAP, meso-diaminopimelic acid; GM-CSF, granulocyte-macrophage colony-stimulating factor; LAL, Limulus amoebocyte lysate assay; LTA, lipoteichoic acid; PG-TA, peptidoglycan-teichoic acid complex; SRBC, sheep red blood cells.
In a protein vaccine, it is important to be aware of any additional components that may possess biological activities e.g. affecting the host's immune response. An evaluation of the expected effects of LTA and PG-TA in such a vaccine on the basis of the reported bioactivities of teichoic acids and PG is difficult because of their different sources and purification methods, and incomplete chemical characterization of the preparations. For this reason, we have now characterized the LTA and PG-TA of the $B$. subtilis production strain 168 (Marburg) both chemically and in respect of a number of bioactivities.

\section{Methods}

Bacterial strain and growth conditions. The Bacillus subtilis strain IH6564 (Himanen et al., 1990) was derived from IH6140, a proteasedeficient derivative of B. subtilis 168 (Marburg) (1A289 in the Bacillus Genetic Stock Center, Ohio State University, Columbus, OH, USA). It was grown as described by Himanen et al. (1991). The cells were collected, washed with physiological saline and freeze-dried as indicated.

Purification of LTA and PG-TA. LTA was prepared according to Fischer et al. (1983). The bacterial cells in $100 \mathrm{~mm}$-sodium citrate buffer (pH 3) were disrupted by vigorous blending in the presence of glass beads and extracted by $40 \%(\mathrm{v} / \mathrm{v})$ phenol, at $\mathrm{pH} 4.7,65^{\circ} \mathrm{C}$. The aqueous phase was dialysed to remove phenol, treated with RNAase at $55^{\circ} \mathrm{C}$ for $2 \mathrm{~h}$, dialysed against $100 \mathrm{~mm}$-sodium acetate $(\mathrm{pH} 4.7)$ and freeze-dried. LTA was further purified by FPLC on Octyl-Sepharose CL-4B (Pharmacia). Crude LTA was applied to the column $(24 \times 370 \mathrm{~mm})$ equilibrated with $15 \%(\mathrm{v} / \mathrm{v}) 1$-propanol in $100 \mathrm{~mm}$ sodium acetate ( $\mathrm{pH} \mathrm{4.7)}$ and eluted with a linear gradient of 1-propanol $(15-70 \%)$ at a flow rate of $0.5 \mathrm{ml} \mathrm{min}-1$. LTA eluted as a distinct fatty- 
acid-containing peak with $65 \%$ 1-propanol. The fatty-acid-containing fractions were pooled, dialysed against water and freeze-dried to yield 23 mg LTA (g dry wt bacteria) ${ }^{-1}$.

PG-TA was prepared as described by Aono \& Horikoshi (1983). The wet bacterial cells in $50 \mathrm{~mm}$-Tris ( $\mathrm{pH} 7.5)$ were disrupted in a French Pressure Cell in the presence of 5 mM-EDTA and 5 mM- $\beta$-mercaptoethanol. The broken cells were extracted with $4 \%$ (w/v) SDS (Fluka) at $100^{\circ} \mathrm{C}$ for $30 \mathrm{~min}$ and subsequently at $37^{\circ} \mathrm{C}$ overnight. The insoluble material was collected by centrifugation $(17000 \mathrm{~g}, 20 \mathrm{~min})$ and washed sequentially with $4 \%$ SDS, water, twice with $1 \mathrm{M}-\mathrm{NaCl}$ and twice with water before freeze-drying to obtain purified PG-TA. The yield was $250 \mathrm{mg}$ (g dry wt bacteria) ${ }^{-1}$.

Animals. The following animals were used as indicated in the text: clinically healthy outbred NIH/S mice, coloured guinea-pigs and Chinchilla-Bastard rabbits (all bred in a conventional environment in National Public Health Institute, Helsinki); inbred BALB/c mice (barrier bred in the Laboratory Animal Centre, University of Helsinki, Helsinki); inbred CBA/N mice and $F_{1}$-hybrid $(\mathrm{CBA} \times \mathrm{C} 57 \mathrm{BL})$ mice (bred in a conventional environment in 'Stolbovaya ' nursery, Academy of Medical Sciences, Moscow).

Chemical methods. Proteins were measured by the Lowry method. A dot-blot method was used for semiquantitative estimation of DNA: $0.4 \mu \mathrm{l}$ of the samples were applied to a $0.9 \%$ agarose plate containing ethidium bromide, and the amount of DNA was estimated under UV light by comparing the intensities of the blots to those obtained with graded amounts of commercial DNA (Boehringer Mannheim). Sodium was determined using a Ciba Corning $614 \mathrm{Na}^{+} / \mathrm{K}^{+}$Analyzer. Phosphate was determined by the method of Lowry et al. (1954) and total hexosamine by the Morgan-Elson reaction after hydrolysis of the samples in $4 \mathrm{M}-\mathrm{HCl}$ at $100^{\circ} \mathrm{C}$ for $16 \mathrm{~h}$ (Strominger et al., 1959). Fatty acids were determined by GLC as their methyl esters after methanolysis using $2 \mathrm{M}-\mathrm{HCl}$ in $\mathrm{MeOH}$ for $7 \mathrm{~h}$ at $86^{\circ} \mathrm{C}$. Neutral sugars were liberated by acid hydrolysis $\left(0 \cdot 1 \mathrm{M}-\mathrm{HCl}, 100^{\circ} \mathrm{C}, 48 \mathrm{~h}\right)$ and determined by $\mathrm{GLC}$ as their alditol acetates (Sawardeker et al., 1967). Alanine and mesodiaminopimelic acid (DAP) were determined as their $N$-heptafluorobutyryl isobutyl esters (Sonesson et al., 1988). Reference DAP and $N$-heptafluorobutyric anhydride were obtained from Sigma. Glycerol was determined by HPLC after hydrolysis of the samples in $5.8 \mathrm{M}-\mathrm{HCl}$ at $100^{\circ} \mathrm{C}$ for $75 \mathrm{~h}$ (Himanen, 1992). Instrumentation and conditions of GLC and combined GLC-MS were summarized recently (Helander et al., 1992).

Test for acute toxicity. The test was performed according to the European Pharmacopoeia (Part 1, V.2.1.5, 2nd edn, 1986), for detecting abnormal toxicity in the last stage of the vaccine production process. Five male NIH/S mice (weighing 17-22 g) and two guinea-pigs (male or female, $250-350 \mathrm{~g}$ ) were used for each preparation. The animals were injected intraperitoneally with the preparations followed by an observation period of $7 \mathrm{~d}$. The animals were weighed before and at the end of the observation period.

Pyrogenicity. The pyrogenicity assay was carried out according to the European Pharmacopoeia (Part 1, V.2.1.4, 2nd edn, 1986). Rectal temperatures of the rabbits (males or females, $2.8-4.3 \mathrm{~kg}$ ) were monitored for $90 \mathrm{~min}$ before and $3 \mathrm{~h}$ after intravenous injections of the preparations $\left(1.0 \mathrm{ml} \mathrm{kg}^{-1}\right)$. Each sample was considered non-pyrogenic if the summed fever response of three rabbits did not exceed $1.15^{\circ} \mathrm{C}$, and pyrogenic if the response exceeded $2.65^{\circ} \mathrm{C}$.

Limulus amoebocyte lysate $(L A L)$ assay. The LAL assay was performed according to Cooper \& Neely (1980) using E-tect lysate (Farmos Diagnostica, Turku, Finland) with a label sensitivity of $0.014 \mathrm{ng} \mathrm{ml}^{-1}$. Endotoxin from Escherichia coli O55:B5 (Whittaker M.A. Bioproducts) was used as a standard. The assay was performed as follows: diluted preparations and endotoxin standard were pipetted into tubes, E-tect lysate was added and the tubes were incubated at $37^{\circ} \mathrm{C}$ for $60 \mathrm{~min}$. If a clot that sustained inversion of the tube was formed, the preparation was considered to be LAL-positive. By comparison with the standard, the amount of LPS in the test sample could be expressed in $\mathrm{ng} \mathrm{ml}^{-1}$.

Mitogenic assay. Spleens of 5-8-week-old CBA/N mice (weight $18-20 \mathrm{~g}$; killed by cervical dislocation) were removed aseptically, cells were teased out, washed and placed in RPMI 1640 medium (Flow Laboratories) supplemented with $5 \%(\mathrm{v} / \mathrm{v})$ heat-inactivated foetal calf serum (Flow), $2 \mathrm{mM}$-L-glutamine (Flow), $50 \mu \mathrm{g}$ gentamicin $\mathrm{ml}^{-1}$ (Flow) and $5 \times 10^{-5} \mathrm{M}$-2-mercaptoethanol (Merck). Cultures containing $2.5 \times 10^{5}$ viable cells were established in microplates. Appropriate concentrations of freeze-dried $B$. subtilis cells, LTA, PG-TA, LPS (E. coli O55:B1; Sigma) or Concanavalin A (ConA; Pharmacia) were added. Cultures were incubated at $37^{\circ} \mathrm{C}, 5 \%(\mathrm{v} / \mathrm{v}) \mathrm{CO}_{2}$ and $100 \%$ humidity, and pulsed with $\left[{ }^{3} \mathrm{H}\right]$ thymidine $[1 \mu \mathrm{Ci}(37 \mathrm{kBq})$ per well $]$. The cells were collected and radioactivity was determined.

Haematopoietic precursor cells. Male BALB/c mice (18-20 g) were injected intraperitoneally with the test preparations. To obtain the control level no injection was done. The mice were killed by cervical dislocation at different times, their femurs prepared, flushed with the medium and the number of cells in the suspension counted. The medium for the bone marrow cultures was Iscove (Flow) enriched with $10 \%$ foetal calf serum (Flow), $50 \mu \mathrm{M}-2$-mercaptoethanol (Merck) and antibiotics (penicillin, streptomycin, and gentamicin; $50 \mu \mathrm{g} \mathrm{ml}^{-1}$ ). Difco Bacto-agar was solubilized in hot water, mixed with the bone marrow cells in complete medium and placed in a water bath at $37^{\circ} \mathrm{C}$. Cell suspensions in agar $(0.3 \%)$ medium were dispensed into plastic culture plates to which a standard GM-CSF-containing material, a supernatant of MK-1 hybridoma cell cultures (kindly donated by Dr L. V. Carcanitsa, Institute of Haematology and Blood Transfusion, Minsk, Belorussia) had been added. The MK-1 hybridoma had been obtained by fusion of ConA-stimulated AKR mouse thymocytes with the syngeneic tumour cell line BW 5147; the conditioned medium of MK-1 cells stimulated the formation of granulocyte and macrophage colonies in semi-solid agar cultures of murine bone marrow cells in a species-specific manner, and there was no evidence of cytokines other than GM-CSF (Carcanitsa, 1988). The cultures were incubated for $7 \mathrm{~d}$ at $37{ }^{\circ} \mathrm{C}$ with $5 \% \mathrm{CO}_{2}$ and $100 \%$ humidity, and the number of colonies was counted. In in vitro experiments the preparations were added to a culture of normal BALB/c mouse bone marrow cells. Cultures were performed in triplicate.

Adjuvant activity. $\mathrm{F}_{1}$-hybrid mice $(\mathrm{CBA} \times \mathrm{C} 57 \mathrm{BL}, 18-20 \mathrm{~g})$ were immunized intravenously with $5 \times 10^{9}$ sheep red blood cells (SRBC) simultaneously with an intraperitoneal injection of 0.1 or $1.0 \mu \mathrm{g}$ of freeze-dried B. subtilis cells, LTA, PG-TA or LPS (E. coli O26:B6, Sigma). Control mice received SRBC only. Spleen cells were collected on day 4 in cold Hanks' BSS, filtered and adjusted to $10^{7}$ viable cells $\mathrm{ml}^{-1}$. Antibody-forming cells were counted according to Jerne \& Nordin (1963) as plaque-forming cells. SRBC were added to a $0.7 \%$ agarose (Sigma) solution and mixed with $10^{6}$ spleen cells of each mouse. The mixtures were poured into dishes, incubated at $35^{\circ} \mathrm{C}$ in the presence of fresh guinea-pig complement, and plaque-forming cells were enumerated.

Statistical methods. Student's $t$-test was used for the calculation of significance; $P<0.05$ was considered significant.

\section{Results and Discussion}

\section{Chemical composition}

Chemical analyses of the isolated LTA revealed a composition typical for Bacillus (Iwasaki et al., 1986, 1989). The main components were glycerol, phosphate, 
Table 1. Chemical composition of the purified PG-TA and LTA of Bacillus subtilis IH6564

\begin{tabular}{lcc}
\hline & \multicolumn{2}{c}{ Composition $\left(\mu \mathrm{mol} \mathrm{mg}^{-1}\right)$} \\
\cline { 2 - 3 } Component & PG-TA & LTA \\
\hline Glucose & 1.6 & 0.13 \\
Ribose & $<0.003$ & $<0.003$ \\
Fatty acids* & 0.0041 & 0.16 \\
Phosphate & 1.7 & 1.9 \\
Hexosamines & 0.89 & 0.73 \\
DAP & 0.39 & $<0.001$ \\
Alanine & 0.53 & $<0.002$ \\
Glycerol & 1.4 & 1.8 \\
Sodium & 1.3 & 1.4 \\
Lowry-positive material & 70 & 17 \\
$\left(\mu \mathrm{g} \mathrm{mg}^{-1}\right)$ & & \\
\hline \hline
\end{tabular}

* Calculated using the molecular mass of pentadecanoic acid (242 Da).

Table 2. In vitro influence on the number of murine bone marrow granulocyte-monocyte colony-forming cells of freeze-dried B. subtilis cells, LTA and $P G-T A$

The preparations were mixed with normal BALB/c mouse bone marrow cells, the suspensions added to $0.9 \%$ agar and dispensed into culture wells to which a standard GM-CSF-containing material had been added. The cultures were incubated for $7 \mathrm{~d}$ at $37^{\circ} \mathrm{C}$, and the number of colonies was counted.

\begin{tabular}{cccc}
\hline \hline \multirow{2}{*}{$\begin{array}{c}\text { Dose } \\
\left(\mu \mathrm{g} \mathrm{ml}^{-1}\right)\end{array}$} & \multicolumn{3}{c}{ Colony-forming cells (mean \pm sEM) } \\
\cline { 2 - 4 } & subtilis cells & LTA & PG-TA \\
\hline $0 \cdot 1$ & $29 \pm 2 \cdot 4$ & $28 \pm 3 \cdot 3$ & $28 \pm 4 \cdot 1$ \\
$1 \cdot 0$ & $30 \pm 2 \cdot 9$ & $45 \pm 4 \cdot 8$ & $30 \pm 3 \cdot 9$ \\
10 & $19 \pm 3 \cdot 2$ & $15 \pm 1 \cdot 6$ & $29 \pm 2 \cdot 3$ \\
100 & $20 \pm 3 \cdot 9$ & 0 & $34 \pm 4 \cdot 1$ \\
Controls: & medium with & $26 \pm 1 \cdot 8$ & \\
& GM-CSF & & \\
& medium without & 0 & \\
& GM-CSF & & \\
\hline \hline
\end{tabular}

fatty acids and glucose (Table 1). There was also a considerable amount of hexosamine, but the amount of alanine was below detection limit. No PG-TA was present in the LTA preparation, since the amount of DAP was below the detection limit.

The chemical composition of the isolated PG-TA (Table 1) also corresponded to the basic structure of its PG-glycero-TA moieties. The molar ratio of hexosamines to DAP was about $2: 1$, and that of glycerol to phosphate about $1: 1$. The amounts of phosphate, hexosamine, DAP, alanine and glycerol $(1 \cdot 7,0 \cdot 9,0 \cdot 4,0 \cdot 5$ and $1.4 \mu \mathrm{mol} \mathrm{mg}^{-1}$, respectively) were in agreement with those reported for $B$. subtilis 168 in other laboratories $\left(1.1-1 \cdot 7,1.0,0.4-0.6,0.5\right.$ and $0.7-1.3 \mu \mathrm{mol} \mathrm{mg}^{-1}$, re- spectively; Fein \& Rogers, 1976; Pooley et al., 1987; Briehl et al., 1989). The purified PG-TA contained traces of membrane-derived material as demonstrated by the detection of $0.004 \mu \mathrm{mol}$ fatty acids $\mathrm{mg}^{-1}$.

No ribose was detected in either LTA or PG-TA, thus excluding the presence of RNA. Semi-quantitative assay on ethidium bromide plates was negative, indicating that the amount of DNA in both LTA and PG-TA was less than $1 \mu \mathrm{g} \mathrm{mg}^{-1}$. The approximately $1: 1$ molar ratio of phosphate to sodium in both LTA and PG-TA showed that they were present in the sodium salt form.

\section{Acute toxicity}

The toxicity of $B$. subtilis cells, LTA and PG-TA was tested by injecting up to $200 \mu \mathrm{g}$ of the preparations in mice and up to $1000 \mu \mathrm{g}$ in guinea-pigs. None of the preparations caused weight loss or symptoms of illness in the animals during $7 \mathrm{~d}$. It was thus concluded that the preparations were devoid of acute toxicity.

\section{Pyrogenicity and Limulus activity}

B. subtilis cells, LTA and PG-TA were pyrogenic in rabbits at doses of 120,30 and $30 \mu \mathrm{g} \mathrm{kg}^{-1}$, respectively and non-pyrogenic at doses of 12,3 and $3 \mu \mathrm{g} \mathrm{kg}^{-1}$, respectively. The pyrogenicity of PG-TA is in accordance with previous reports on other peptidoglycans (Heymer \& Rietschel, 1977; Stewart-Tull, 1980). Since LTA, on the other hand, has been described as non-pyrogenic (Wicken \& Knox, 1980), we used the LAL-assay to test the possibility that our preparations contained LPS as a contaminant responsible for the observed pyrogenicity. The minimal concentrations of LTA, PG-TA and standard LPS that yielded a positive LAL-reaction were $0 \cdot 3,30$ and $6.8 \times 10^{-6} \mu \mathrm{g} \mathrm{ml}^{-1}$, respectively. Assuming that all LAL-positive material was LPS, we calculated the maximal amount of LPS present in the preparations, and from it the maximal amount of LPS per pyrogenic dose. This turned out to be $0.7 \mathrm{ng}$ for LTA and $0.007 \mathrm{ng}$ for PG-TA. By comparing these data with the minimal pyrogenic dose of LPS (of the order of $1 \mathrm{ng} \mathrm{kg}^{-1}$; Kuronen et al., 1977; Muotiala et al., 1992), we concluded that the temperature rise seen in rabbits injected with LTA could have been due to contaminating LPS, whereas that seen with PG-TA was clearly due to its inherent pyrogenicity. Since a positive reaction in the LAL-assay has been claimed to be not LPS-specific but rather a result of the unique reactivity of amphipathic molecules (Wicken \& Knox, 1980), we cannot exclude the possibility that the temperature rise seen by using LTA could also have been due to its inherent pyrogenicity. 

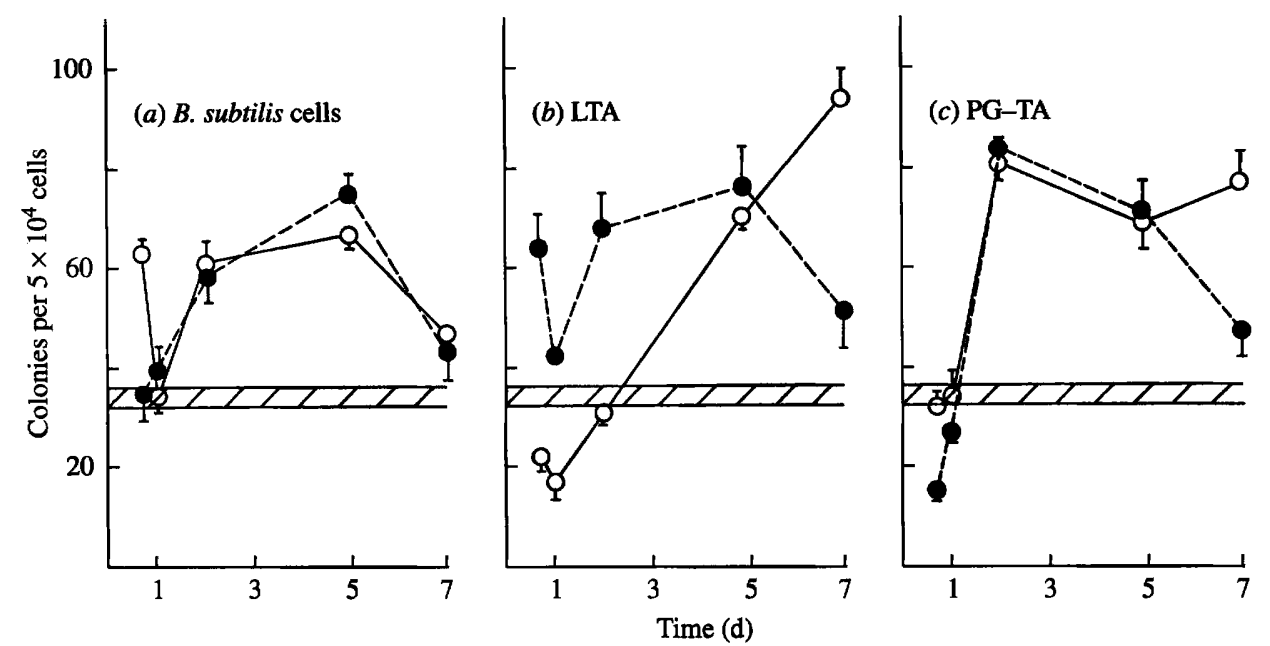

Fig. 1. In vivo influence on the number of murine bone marrow granulocyte-monocyte colony-forming cells of $B$. subtilis cells (a), purified LTA $(b)$ and PG-TA $(c)$. Mice were injected intraperitoneally with the preparations $[(O) 0.1 \mu \mathrm{g}$ per mouse; $(0) 1.0 \mu \mathrm{g}$ per mouse] and killed at different times. Cell suspensions of their bone marrow cells were prepared, mixed with $0.9 \%$ agar and dispensed into plastic dishes to which a standard GM-CSF-containing material had been added. The cultures were incubated for $7 \mathrm{~d}$ at $37{ }^{\circ} \mathrm{C}$, and the number of colonies was counted. The horizontal bar represents the control level obtained without injecting any of the preparations (mean of all the points \pm SEM).

\section{Mitogenicity}

We quantified the mitogenicity of our preparations as their ability to stimulate the incorporation of $\left[{ }^{3} \mathrm{H}\right]$ thymidine in mouse spleen cells. LPS and ConA were used as standard mitogens at their optimal concentrations (100 $\mu \mathrm{g} \mathrm{ml}^{-1}$ and $2 \mu \mathrm{g} \mathrm{ml}^{-1}$, respectively), and were found to cause a 15-20-fold stimulation compared to the culture incubated with medium only. At the highest test concentration of $100 \mu \mathrm{g} \mathrm{ml}^{-1}, B$. subtilis cells showed a weak-about twofold-and PG-TA about fourfold stimulation. We found no mitogenicity in LTA at any concentration $\left(0.01-100 \mu \mathrm{g} \mathrm{ml}^{-1}\right)$; instead, concentrations of $1-100 \mu \mathrm{g} \mathrm{m}^{-1}$ showed a suppressing, probably cytotoxic effect (to be discussed below). According to Beachey et al. (1979), streptococcal LTA is a mitogen for human and mouse lymphocytes, especially $\mathrm{T}$ cells. The effect on mouse cells was reported to be strongly concentration-dependent, with a stimulation at 0.005$0.05 \mu \mathrm{g} \mathrm{ml}^{-1}$, and suppression at $0.5-50 \mu \mathrm{g} \mathrm{ml}^{-1}$.

\section{GM-CSF responses}

Granulocyte-macrophage colony-stimulating factor (GM-CSF) is defined as a molecule able to stimulate the proliferation of bone marrow progenitors of granulocytes and macrophages to form colonies on in vitro culture (for a review, see Metcalf, 1990). GM-CSF stimulates the generation of erythroid and myeloid cells in the bone marrow and regulates their functions. Wellknown substances capable of inducing the production of GM-CSF are LPS (Metcalf, 1971; Quesenberry et al.,
1972; Moore et al., 1979), phytohaemagglutinin and monokines such as IL-1 and TNF (Gasson, 1991). LPS also directly affects colony formation by increasing the responsiveness of progenitor cells to GM-CSF (Moore et al., 1980). There are few data on the effects of LTA or PG on the induction of GM-CSF, but PG from Escherichia coli (Staber \& Metcalf, 1980) and synthetic muramyldipeptide (Galelli \& Chedid, 1983) have been shown to increase production of GM-CSF in vivo.

In vitro studies. We first investigated the effect of $B$. subtilis-derived components on the in vitro responsiveness of colony-forming cells to GM-CSF. Upon addition to a culture of mouse bone marrow cells incubated with a standard dose of GM-CSF, LTA at a concentration of $1.0 \mu \mathrm{g} \mathrm{ml}^{-1}$ induced an increase in the number of colonies, whereas neither $B$. subtilis cells nor PG-TA had such an effect (Table 2). The effect of LTA was, however, weak in comparison to LPS, which has been reported to possess a maximal stimulating effect at concentrations of $0 \cdot 1-10 \mathrm{ng} \mathrm{ml}^{-1}$ (Moore et al., 1979, 1980). As a further control, mouse bone marrow cells were incubated under the same conditions but without GM-CSF; none of the preparations induced any colony-forming cells (data not shown).

At higher concentrations, LTA brought about a dramatic drop in the number of colonies (Table 2), suggesting a cytotoxic effect. Other authors have also described cytotoxicity of high concentrations $\left(50 \mu \mathrm{g} \mathrm{ml}^{-1}\right.$ or more) of LTA in cultures of murine splenocytes (Bolton, 1981), mouse fibroblasts (Leon \& Panos, 1983), and human heart cells (Courtney et al., 1986). Courtney et al. (1986) and Sutcliffe \& Shaw (1991) have suggested 
Table 3. Adjuvant effect of freeze-dried B. subtilis cells, LTA and PG-TA on anti-SRBC plaque-forming cell generation of $F_{1}$-hybrid $(C B A \times C 57 B L)$ mice in vivo

\begin{tabular}{|c|c|c|c|c|c|}
\hline \multirow[b]{2}{*}{ Component } & \multirow{2}{*}{$\begin{array}{c}\text { Dose } \\
(\mu \mathrm{g})\end{array}$} & \multicolumn{4}{|c|}{ Stimulation index } \\
\hline & & Expt 1 & Expt 2 & Expt 3 & Mean values \\
\hline B. subtilis cells & $\begin{array}{l}0.1 \\
1.0\end{array}$ & $\begin{array}{l}1 \cdot 12(5) \\
1 \cdot 26^{*}(5)\end{array}$ & $\begin{array}{l}0.75(5) \\
1.39^{*}(5)\end{array}$ & $\begin{array}{l}\text { ND } \\
\text { ND }\end{array}$ & $\begin{array}{l}0.94(10) \\
1.33^{*}(10)\end{array}$ \\
\hline LTA & $\begin{array}{l}0.1 \\
1.0\end{array}$ & $\begin{array}{l}1 \cdot 39 *(5) \\
1.00(6)\end{array}$ & $\begin{array}{l}\text { ND } \\
\text { ND }\end{array}$ & $\begin{array}{l}1 \cdot 55^{*}(5) \\
1 \cdot 11(4)\end{array}$ & $\begin{array}{l}1.47^{*}(10) \\
1.06(10)\end{array}$ \\
\hline PG-TA & $\begin{array}{l}0 \cdot 1 \\
1 \cdot 0\end{array}$ & $\begin{array}{l}1 \cdot 25^{*}(6) \\
1.31^{*}(5)\end{array}$ & $\begin{array}{l}0.83(3) \\
1.21 *(4)\end{array}$ & $\begin{array}{l}0.97(5) \\
1.20(4)\end{array}$ & $\begin{array}{l}1.02(14) \\
1.24 *(13)\end{array}$ \\
\hline $\begin{array}{l}E . \text { coli }(\mathrm{O} 26: \mathrm{B} 6) \\
\text { LPS }\end{array}$ & $\begin{array}{l}0.1 \\
1.0\end{array}$ & $\begin{array}{l}1 \cdot 13(5) \\
2 \cdot 81^{*}(5)\end{array}$ & $\begin{array}{l}1.88^{*}(5) \\
3.31 *(5)\end{array}$ & $\begin{array}{l}1.56^{*}(3) \\
1.84^{*}(4)\end{array}$ & $\begin{array}{l}1 \cdot 48^{*}(13) \\
2 \cdot 65^{*}(14)\end{array}$ \\
\hline
\end{tabular}

* Indicates a significant difference between the control and experimental groups $(P<0.05)$. ND, Not determined.

that LTA may be cytotoxic for cells only above its critical micellar concentration. This could explain the inhibition of colony formation seen at high concentrations of our LTA-preparation, since the critical micellar concentration of LTA from several species of bacteria has been reported to be relatively high $(28-60 \mu \mathrm{g}$ $\mathrm{ml}^{-1}$ in phosphate-buffered saline; Courtney et al., 1986).

In vivo studies. B. subtilis cells, LTA and PG-TA were injected into BALB/c mice at a concentration of $0.1 \mu \mathrm{g}$ or $1.0 \mu \mathrm{g}$, and the number of colony-forming cells in their bone marrow was determined after $16 \mathrm{~h}$ and 1, 2, 5 and $7 \mathrm{~d}$ (Fig. 1). Each of the preparations induced an increase in the numbers of bone marrow colony-forming cells, best seen between days 2 and 5 . In most experiments, the effect was already disappearing on day 7 . The increase in colony numbers was probably due to an increase in the production of GM-CSF.

\section{Adjuvant activity}

We found evidence for adjuvant activity with each of the preparations (Table 3). Both $B$. subtilis cells and PG-TA had a small but statistically significant adjuvant effect at the larger dose (1.0 $\mu \mathrm{g}$ per mouse). LTA increased the SRBC-specific plague-forming cell response only at the lower dose $(0.1 \mu \mathrm{g}$ per mouse). Other adjuvants, including lipid-free LTA, have also been shown to enhance or suppress the immune response depending upon the dose and timing (Chorpenning et al., 1979). LPS stimulated the plaque-forming cell response at both concentrations $(0.1$ and $1.0 \mu \mathrm{g}$ per mouse) tested, in a dose-dependent manner. A decrease in response was not observed with any dose of any of the substances tested.

\section{Concluding remarks}

In this study we assessed the biological activities of purified and chemically characterized LTA and PG-TA from a derivative of $B$. subtilis 168 (Marburg), which is a suitable host for producing heterologous vaccine proteins and other pharmaceuticals. Previous reports of biological activities of LTA and PG-TA contain many discrepancies, probably due to different sources and hence different chemical structures of the preparations used. In particular, the 2-OH substitution and the salt form of glycerol-phosphate polymers may influence the responses seen in the biological assays. Thus, a proper chemical characterization of the preparations used was essential, especially since sensitive and accurate analytical methods are available nowadays.

LTA and PG-TA were found to be non-toxic. PG-TA and possibly LTA were weakly pyrogenic. Putative heterologous vaccine proteins obtained from derivatives of B. subtilis 168 (Marburg) have been estimated to contain $1 \%$ or less of PG-TA and $4 \%$ or less of LTA (Himanen et al., 1993). One human vaccine dose (estimated as $50 \mu \mathrm{g}$ protein) would thus contain $0.5 \mu \mathrm{g}$ or less of PG-TA and $2 \mu \mathrm{g}$ or less of LTA. On the basis of our present results, these amounts are clearly below the pyrogenic dose of PG-TA and LTA $(30 \mu \mathrm{g})$. These amounts of both LTA and PG-TA could have immunostimulatory effects: in mice a dose of 0.1 and/or $1.0 \mu \mathrm{g}$ of 
both compounds increased the number of bone marrow granulocyte-monocyte colony-forming cells and exhibited adjuvant activity for antibody production. The level and duration of the stimulatory effect of bacillar components upon GM-CSF production is of interest, because of its probable role in inducing resistance to viruses (human immunodeficiency virus; Groopman et al., 1987) and bacteria (Salmonella typhimurium; Morrissey et al., 1989). Hence, in respect to vaccine production the minute amounts of LTA and PG-TA in the purified heterologous proteins produced in $B$. subtilis 168 (Marburg) are not expected to cause harmful effects; instead, they may have beneficial effects on host defence.

We thank P. H. Mäkelä for critical reading of the manuscript. The work was financially supported by the Academy of Finland, the National Agency for Welfare and Health in Finland, and Pasteur Mérieux Serums et Vaccins, Lyon, France (under a research contract with VTT Technology, Inc., Espoo, Finland).

\section{References}

Aono, R. \& Horikoshi, K. (1983). Chemical composition of cell walls of alkalophilic strains of Bacillus. Journal of General Microbiology 129, 1083-1087.

Beachey, E. H., Dale, J. B., Grebe, S., Ahmed, A., Simpson, W. A. \& OFEK, I. (1979). Lymphocyte binding and T cell mitogenic properties of group A Streptococcal lipoteichoic acid. Journal of Immunology 122, 189-195.

BolToN, R. W. (1981). Modulation of murine lymphocyte mitogen responses by glycerol-teichoic acid. Immunological Communications 10, 631-640.

Briehl, M., Pooley, H. M. \& Karamata, D. (1989). Mutants of Bacillus subtilis 168 thermosensitive for growth and wall teichoic acid synthesis. Journal of General Microbiology 135, 1325-1334.

CARCANITSA, L. V. (1988). T-T hybridoma as a model for hemopoietic growth factor studies. In Materials and Methods for the Biospecific Corrections in Hematology and Transfusion (in Russian), pp. 50-51. Edited by E. P. Ivanov. Minsk: The Ministry of Health of Belorussia. ChORPENNIng, F. W., LYNCH, J. J., JR, COOPER, H. R. \& OldFATHER, J. W. (1979). Modulation of the immune response to sheep erythrocytes by lipid-free glycerol teichoic acid. Infection and Immunity 26, 262-269.

COOPER, J. F. \& NEELY, M. E. (1980). Validation of the LAL test for end-product evaluation. Pharmaceutical Technology 4, 72-79.

Courtney, H. S., Simpson, W. A. \& Beachey, E. H. (1986). Relationship of critical micelle concentrations of bacterial lipoteichoic acids to biological activities. Infection and Immunity 51, 414-418.

Debabov, V. G. (1982). The industrial use of bacilli. In The Molecular Biology of the Bacilli, vol. 1, pp. 331-370. Edited by D. A. Dubnau. London: Academic Press.

FEIN, J. E. \& RoGERs, H. J. (1976). Autolytic enzyme-deficient mutants of Bacillus subtilis 168. Journal of Bacteriology 127, 1427-1442.

FISCHER, W., KoCH, H. U. \& HAAS, R. (1983). Improved preparation of lipoteichoic acids. European Journal of Biochemistry 133, 523-530.

GALELLI, A. \& CHEDID, L. (1983). Modulation of myelopoiesis in vivo by synthetic adjuvant-active muramyl peptides : induction of colonystimulating activity and stimulation of stem cell proliferation. Infection and Immunity 42, 1081-1085.

Gasson, J. C. (1991). Molecular physiology of granulocytemacrophage colony-stimulating factor. Blood 77, 1131-1145.

Groopman, J. E., Mitsuyasu, R. T., Deleo, M. J., Oette, D. H. \& GoLDE, D. W. (1987). Effect of recombinant human granulocytemacrophage colony-stimulating factor on myelopoiesis in the acquired immunodeficiency syndrome. New England Journal of Medicine 317, 593-597.
HaRwOoD, C. R. (1992). Bacillus subtilis and its relatives: molecular, biological and industrial workhorses. Trends in Biotechnology 10, 247-256.

Helander, I. M., Hurme, R., Haikara, A. \& Moran, A. P. (1992). Separation and characterization of two chemically distinct lipopolysaccharides in two Pectinatus species. Journal of Bacteriology 174, 3348-3354.

HEYMER, B. \& RIETSCHEL, E. T. (1977). Biological properties of peptidoglycans. In Microbiology, pp. 344-349. Edited by D. Schlessinger. Washington, DC: American Society for Microbiology.

HimANEN, J.-P. (1992). Determination of glycerol in bacterial cell wall teichoic acid by high performance liquid chromatography. Journal of Chromatography 607, 1-6.

Himanen, J.-P., Taira, S., Sarvas, M., Saris, P. \& RunEberg-Nyman, K. (1990). Expression of pertussis toxin subunit $S 4$ as an intracytoplasmic protein in Bacillus subtilis. Vaccine 8, 600-604.

Himanen, J.-P., HyvärInEN, T., Ölander, R.-M., RuNEBERG-NyMan, K. \& SaRvaS, M. (1991). The $20 \mathrm{kDa}$ C-terminally truncated form of pertussis toxin subunit $\mathrm{S} 1$ secreted from Bacillus subtilis. FEMS Microbiology Letters 79, 115-120.

Himanen, J.-P., Sarvas, M. \& Helander, I. M. (1993). Assessment of non-protein impurities in potential vaccine proteins produced by Bacillus subtilis. Vaccine 11, 970-973.

Iwasaki, H., Shimada, A. \& Ito, E. (1986). Comparative studies of lipoteichoic acids from several Bacillus strains. Journal of Bacteriology 167, 508-516.

Iwasaki, H., Shimada, A., Yokoyama, K. \& Ito, E. (1989). Structure and glycosylation of lipoteichoic acids in Bacillus strains. Journal of Bacteriology 171, 424-429.

Jerne, N. K. \& Nordin, A. A. (1963). Plaque formation in agar by single antibody-producing cells. Science 140, 405.

Kuronen, T., Peltola, H., Nors, T., Haque, N. \& Mäkelä, P. H. (1977). Adverse reactions and endotoxin content of polysaccharide vaccines. Developments in Biological Standardization 34, 117-125.

Leon, O. \& Panos, C. (1983). Cytotoxicity and inhibition of normal collagen synthesis in mouse fibroblasts by lipoteichoic acid from Streptococcus pyogenes type 12. Infection and Immunity 40, 785-794.

LOWRY, O. H., ROBERTS, N. R., LeINER, K. Y., WU, M. L. \& FARR, A. L. (1954). The quantitative histochemistry of brain. I. Chemical methods. Journal of Biological Chemistry 207, 1-17.

MeTCALF, D. (1971). Acute antigen-induced elevation of serum colony stimulating factor (CSF) levels. Immunology 21, 427-436.

MetCALF, D. (1990). The colony stimulating factors. Molecular, cellular and clinical aspects. In Growth Factors in Health and Disease, pp. 333-347. Edited by B. Westermark, C. Betsholtz \& B. Hökfelt. Amsterdam: Elsevier Science Publishers.

Moore, R. N., UrbascheK, R., Wahl, M. L. \& Mergenhagen, S. E. (1979). Prostaglandin regulation of colony-stimulating factor production by lipopolysaccharide-stimulated murine leukocytes. Infection and Immunity 26, 408-414.

Moore, R. N., Steeg, P. S., Männel, D. N. \& Mergenhagen, S. E. (1980). Role of lipopolysaccharide in regulating colony-stimulating factor-dependent macrophage proliferation in vitro. Infection and Immunity 30, 797-804.

Morrissey, P. J., Grabstein, K. H., Reed, S. G. \& Conlon, P. J. (1989). Granulocyte/macrophage colony stimulating factor. A potent activation signal for mature macrophages and monocytes. International Archives of Allergy and Applied Immunology 88, 40-45.

Muotiala, A., Helander, I. M., PyhäLä, L., Kosunen, T. U. \& MORAN, A. P. (1992). Low biological activity of Helicobacter pylori lipopolysaccharide. Infection and Immunity 60, 1714-1716.

NURMINEN, M., BUTCHER, S., IDÄNPÄÄN-HEIKKIL Ä, I., WAHLSTRÖM, E., Muttilainen, S., Runeberg-Nyman, K., Sarvas, M. \& Mäkel ä, P. H. (1992). The class 1 outer membrane protein of Neisseria meningitidis produced in Bacillus subtilis gives rise to protective immunity. Molecular Microbiology 6, 2499-2506.

Pooley, H. M., Paschoud, D. \& Karamata, D. (1987). The gtaB marker in Bacillus subtilis 168 is associated with a deficiency in UDP glucose pyrophosphorylase. Journal of General Microbiology 133, 3481-3493.

Quesenberry, P., Morley, A., Stohlman, F., JR, Rickard, K., HowARD, D. \& SMITH, M. (1972). Effect of endotoxin on 
granulopoiesis and colony-stimulating factor. New England Journal of Medicine 286, 227-232.

RuneberG-Nyman, K., ENGSTRöm, O., LöFDAhL, S., Ylöstalo, S. \& SARVAS, M. (1987). Expression and secretion of pertussis toxin subunit $\mathrm{S} 1$ in Bacillus subtilis. Microbial Pathogenesis 3, 461-468.

Sarvas, M., Kontinen, V., Himanen, J.-P., Saris, P., Taira, S. \& RUNEBERG-NYMAN, K. (1990). Secretion and production of foreign proteins in Bacillus. In Proceedings of the International Symposium on Genetics of Industrial Microorganisms, pp. 147-158. Edited by H. Heslot, J. Davies, J. Florent, L. Bobichon, G. Durand \& L. Penasse. Strasbourg: Société Française de Microbiologie.

SAWARDEkER, J. S., SLONEKer, J. H. \& JEANES, A. (1967). Quantitative determination of monosaccharides as their alditol acetates by gas liquid chromatography. Analytical Chemistry 37, 1602-1604.

Sonesson, A., LARSSON, L., FoX, A., Westerdaht, G. \& OdHam, G. (1988). Determination of environmental levels of peptidoglycan and lipopolysaccharide using gas chromatography with negative-ion chemical-ionization mass spectrometry utilizing bacterial amino acids and hydroxy fatty acids as biomarkers. Journal of Chromatography 431, 1-15.

Staber, F. G. \& Metcalf, D. (1980). Cellular and molecular basis of the increased splenic hemopoiesis in mice treated with bacterial cell wall components. Proceedings of the National Academy of Sciences of the United States of America 77, 4322-4325.

STEWART-Tull, D. E. S. (1980). The immunological activities of bacterial peptidoglycans. Annual Review of Microbiology 34, 311-340.

Strominger, J. L., Park, J. T. \& Thompson, R. E. (1959). Composition of the cell wall of Staphylococcus aureus: its relation to the action of penicillin. Journal of Biological Chemistry 234, 3263-3268.

SuTClifFe, I. C. \& SHAw, N. (1991). Atypical lipoteichoic acids of Gram-positive bacteria. Journal of Bacteriology 173, 7065-7069.

WICKEN, A. J. \& KNox, K. W. (1980). Bacterial cell surface amphiphiles. Biochimica et Biophysica Acta 604, 1-26. 